\title{
Improvement of the Logical Intelligence Through Media Kolak (Collage Numbers) Based on Local Wisdom in Early Childhood
}

\author{
Novi Ade Suryani ${ }^{1 凶}$, Mimpira Haryono ${ }^{2}$ \\ Prodi PG-PAUD, Fakultas Keguruan dan Ilmu Pendidikan, Universitas Dehasen \\ Bengkulu, Indonesia
}

\begin{abstract}
This study aims to improve logical intelligence through media kolak (collage numbers) based on local wisdom in early childhood in PAUD Mawar Al Barokah, Padang Serai Village, Kampung Melayu District, Bengkulu City. The procedure for carrying out this research was carried out using two cycles. Each cycle consists of four stages, namely planning, acting, observing, and reflecting. Each cycle also consists of two meetings, where each meeting has three assessments 1). Know the shape of objects, 2). Know the concept of numbers, and 3). Calculate the number of objects. The results showed an increase that the end of the second cycle was higher than the end of the first cycle in the category of Very Good Developing Children (BSB), namely at the stage of recognizing the shape of objects by $84 \%$, knowing the concept of numbers by $64 \%$, and at the stage of calculating the number of objects of $72 \%$. In addition, from the learning process it seems fun by using natural materials that are easily available, students become more active, enthusiastic, and creative. Thus, learning through media kolak (collage numbers) based on local wisdom can be used by teachers to improve logic intelligence in early childhood.
\end{abstract}

Keywords: logic intelligence, number collage, local potential

\begin{abstract}
Abstrak
Penelitian ini bertujuan untuk meningkatkan kecerdasan logika melalui media kolak (kolase angka) berbasis kearifan lokal pada anak usia dini di PAUD Mawar Al Barokah Kelurahan Padang Serai Kecamatan Kampung Melayu Kota Bengkulu. Prosedur pelaksanaan penelitian ini dilakukan dengan menggunakan dua siklus. Setiap siklus terdiri dari empat tahapan yaitu perencanaan (planning), tindakan (acting), pengamatan (observing), dan refleksi (reflecting). Setiap siklus juga terdiri dari dari dua pertemuan, dimana setiap pertemuan terdapat tiga kali penilaian 1). Mengenal bentuk benda, 2). Mengenal konsep angka, dan 3). Menghitung jumlah bentuk benda. Hasil penelitian menunjukkan adanya peningkatan bahwa akhir siklus dua lebih tinggi dari akhir siklus satu pada kategori anak Berkembang Sangat Baik (BSB) yakni pada tahapan mengenal bentuk benda sebesar $84 \%$, mengenal konsep angka sebesar $64 \%$, dan pada tahapan menghitung jumlah bentuk benda sebesar $72 \%$. Di samping itu, dari proses pembelajaran tampak menyenangkan dengan menggunakan bahan alam yang mudah didapat, siswa menjadi lebih aktif, antusias, dan kreatif. Dengan demikian, pembelajaran melalui media kolak (kolase angka) berbasis kearifan lokal dapat digunakan oleh guru untuk meningkatkan kecerdasan logika pada anak usia dini.
\end{abstract}

Kata Kunci: kecerdasan logika, kolase angka, potensi local

@ Jurnal Obsesi Prodi PG-PAUD FIP UPTT 2018

$\triangle$ Corresponding author :

Address : Jl. Jaya Wijaya Bengkulu

ISSN 2356-1327 (Media Cetak)

Email : noviade@unived.ac.id

ISSN 2549-8959 (Media Online) 
PENDAHULUAN

Pendidikan mempunyai peranan penting dalam pembangunan manusia Indonesia. Oleh karenanya pendidikan sangat perlu untuk dikembangkan dari berbagai ilmu pengetahuan, karena pendidikan yang berkualitas dapat meningkatkan kecerdasan suatu bangsa.

Sementara itu Komisi tentang Pendidikan Abad 21(Commision on Education for The "21" Century), merekomendasikan empat strategi dalam mensukseskan pendidikan (Trianto,2008) ; pertama, learning to learn, yaitu memuat bagaimana pelajar mampu menggali informasi yang ada di sekitarnya dari ledakan informasi itu sendiri; kedua, learning to be, yaitu pelajar diharapkan mampu untuk mengenali dirinya sendiri, serta mampu beradaptasi dengan lingkungannya; ketiga, learning to do, yaitu berupa tindakan atau aksi untuk memunculkan ide yang berkaitan dengan matematika; dan keempat, learning to be together, yaitu memuat bagaimana kita hidup dalam masyarakat yang saling bergantung antara satu dengan yang lain, sehingga mampu bersaing secara sehat dan bekerjasama serta mampu untuk menghargai orang lain.

Undang-Undang Sisdiknas No. 20/2003 pasal 1 angka 14 menyebutkan Pendidikan Anak Usia Dini (PAUD) merupakan upaya pembinaan yang dilakukan melalui pemberian rangsangan pendidikan dengan tujuan untuk mengembangkan seluruh potensi anak agar kelak dapat berfungsi sebagai manusia yang cerdas dan bermanfaat bagi bangsa. Anak Usia Dini (AUD) merupakan kelompok usia yang berada dalam proses perkembangan unik, karena proses perkembangannya (tumbuh dan kembang) terjadi bersama dengan golden age (masa peka).

Pendidikan yang diberikan pada anak usia dini baik di Pos PAUD, Kelompok Bermain (KB), maupun Taman Kanakkanak (TK) dimaksudkan untuk membantu anak mencapai tahap perkembangannya secara optimal dan disesuaikan dengan usia dan kemampuan anak. Stimulus-stimulus yang diberikan seharusnya dapat mengembangkan aspek perkembangan anak secara keseluruhan yang meliputi aspek kognitif, bahasa, sosial, emosional, dan fisik motorik.

Perkembangan kognitif anak dalam mengenal angka sangat penting untuk dikuasai oleh anak, karena akan menjadi dasar bagi penguasaan konsep-konsep matematika selanjutnya di jenjang pendidikan berikutnya.

Memahami konsep angka adalah sesuatu yang sangat penting bagi anakanak. Ini karena angka yang selalu kita gunakan sepanjang proses kehidupan. Juga memahami angka adalah langkah pertama pelajaran matematika, tanpa memahami angka, maka seorang anak akan mengalami kesulitan dalam tahap pembelajaran berikutnya (Hasiana,2017).

Pada awalnya, anak akan belajar nama-nama bilangan tetapi belum mampu menilai lambing lambangnya, misalnya mereka bisa menyebut, satu, dua, tiga, tetapi belum mampu memahami artinya. Seringkali bilangan disebut seperti rangkaian kata-kata tanpa makna yang berkaitan dengan bilangan itu. Sejalan dengan pertumbuhan dan pengalaman yang diperolah, anak akan mampu memahami arti dari suatu angka. Mufarizuddin (2017) menyebutkan bahwa penomoran pada kartu juga dapat meeningkatkan kecerdasan logika matematika anak.

Penggunaan benda alam dalam melalui kegiatan kolase dengan benda pada anak akan mempermudah pemahaman anak tentang angka, karena angka bersifat abstrak selain itu pembelajaran juga akan menjadi saangat menarik dan menyenangkan. Anak akan memperoleh informasi demi informasi melalui interaksinya dengan objek dan alam sekitar serta kelak informasi tersebut disusun menjadi struktur pengetahuan. Struktur pengetahuan inilah kemudian menjadi dasar untuk berfikir.

Kata kecerdasan diambil dari akar kata cerdas. Menurut Kamus Besar Bahasa Indonesia cerdas berarti sempurna perkembangan akal budi seseorang manusia untuk berfikir, mengerti, tajam 
pikiran dan sempurna pertumbuhan tubuhnya. Kecerdasan ialah istilah umum yang digunakan untuk menjelaskan sifat pikiran yang mencakup sejumlah kemampuan, seperti kemampuan menalar, merencanakan, memecahkan masalah, berpikir abstrak, memahami gagasan, menggunakan bahasa, dan belajar (Makmun,2003).

Dalam buku Robert. J. Sternbrg oleh Jensen(2005), Burt mendefinisikan kecerdasan sebagai kemampuan kognitif umum bawaan, dan banyak psikolog, Jensen salah satunya, cenderung menerima konsep kecerdasan yang dikemukakan Burt. Definisi itu meliputi:

a. Definisi „riile meyakini kecerdasan bersifat bawaan, atau dengan kata lain, kecerdasan diwarisi dari orang tua dan sudah dimiliki sejak lahir (diturunkan secara genetik).

b. Definisi ,riil ${ }^{\text {ee }}$ meyakini kecerdasan melalui kognitif (dengan kata lain, hanya terkait dengan yang diketahui atau dipikirkan manusia).

Berdasarkan beberapa pendapat tersebut peneliti menyimpulkan bahwa kecerdasan merupakan sebuah perkembangan berpikir atau kemampuan seseorang untuk memecahkan masalah. Kecerdasan yang dimiliki setiap orang berbeda-beda. Seseorang yang memiliki inteligensi yang lebih baik, kemungkinan untuk menemukan sistem yang lebih baik pasti lebih besar, dan berbagai kemudahan bisa disediakan bagi yang membutuhkan.

Kecerdasan logika atau kecerdasan logis mateematis merupakan kecerdasan yang berkaitan dengan angka dan segala implikasinya. Selanjutnya Fathani (2009) mengungkapkan bahwa kecerdasan logis matematis merupakan kemampuan berpikir dengan menerapkan logika yang benar, memahami, dan menganalisis pola-pola, serta memecahkan masalah dengan menggunakan kemampuan berpikir.

Menurut Sulaiman (2014) Adapaun faktor-faktor yang mempengaruhi Inteligensi terbagi menjadi dua: Pertama, faktor Bawaan atau Keturunan. Penelitian membuktikan bahwa korelasi nilai tes IQ dari satu keluarga sekitar 0,50. Sedangkan di antara 2 anak kembar, korelasi nilai tes IQnya sangat tinggi, sekitar 0,90. Bukti lainnya adalah pada anak yang diadopsi. IQ mereka berkorelasi sekitar 0,40 - 0,50 dengan ayah dan ibu yang sebenarnya, dan hanya $0,10-0,20$ dengan ayah dan ibu angkatnya. Selanjutnya bukti pada anak kembar yang dibesarkan secara terpisah, IQ mereka tetap berkorelasi sangat tinggi, walaupun mungkin mereka tidak pernah saling kenal (Agustian,2001).

Kedua, Faktor lingkungan. Walaupun ada ciri-ciri yang pada dasarnya sudah dibawa sejak lahir, ternyata lingkungan sanggup menimbulkan perubahanperubahan yang berarti. Inteligensi tentunya tidak bisa terlepas dari otak. Perkembangan otak sangat dipengaruhi oleh gizi yang dikonsumsi. Selain gizi, rangsanganrangsangan yang bersifat kognitif emosional dari lingkungan juga memegang peranan yang amat penting (Sukmadinata,2005).

Kecerdasan logika merupakan kecerdasan yang dapaat diukur. Mereka berfikir secara konseptual dalam kerangka pola pola angka dan mampu membuat hubungan hubungan antara berbagai ragam informasi yang didapat. Mereka selalu ada rasa ingin tahu tentang dunia disekeliling mereka dan selalu menanyakan banyak hal serta mau mengerjakan eksperimentasi. Selalu mempermasalahkan dan menanyakan kejadian-kejadian yang ada, sehingga tak jarang mereka agak tak disukai atau membosankan karena terlalu banyak bertanya (Sulaiman,2014).

Kolase berasal dari Bahasa Perancis (collage) yang berarti merekat. Kolase adalah aplikasi yang dibuat dengan menggabungkan teknik melukis (lukisan tangan) dengan menempelkan bahan-bahan tertentu (Sumanto, 2005).

Menurut kamus besar Bahasa Indonesia, kolase adalah komposisi artistik yang dibuat dari berbagai bahan (kain, kertas, kayu) yang ditempelkan pada permukaan gambar (Depdiknas.2001).

Kolase merupakan karya seni rupa dua dimensi yang menggunakan bahan yang ebrmacam-macam selama bahan dasar tersebut dapat dipadukan dengan 
bahan dasar lain yang akhirnya dapat menyatu menjadi karya yang utuh dan dapat mewakili ungkapan perasaan estetis orang yang membuatnya. Sehingga dapat dikatakan bahwa bahan apapun yang dapat dirangkum (dikolaborasikan) sehingga menjadi karya senu rupa dua dimensi, dapat digolongkan / dijadikan bahan kolase.

Kegiatan kolase dalam penelitian ini adalah kegiatan berolah seni rupa yang menggabungkan teknik melukis (lukisan tangan) dengan keterampilan menyusun dan merekatkan bahan-bahan pada kertas gambar/bidang dasaran yang digunakan, sampai dihasilkan tatanan yang unik, menarik dan berbeda menggunakan bahan kertas, bahan alam dan bahan buatan.

Berdasarkan uraian dari kedua pendapat di atas untuk memfokuskan bahan yang aman dan menarik serta mudah didapatkan dalam pembuatan kolase untuk anak di TK menggunakan alat bidang dasaran berupa kertas hvs, kertas gambar, lem kayu, lem kertas, gunting dan pensil, serta menggunakan bahan alam dan kertas seperti kertas lipat, kertas bungkus kado, koran bekas, majalah bekas, kulit bawang merah, kulit bawang putih, padi,biji kopi, biji jagung dan biji kacang hijau.

Menurut Sujiono (2013) usia dini lahir sampai enam tahun merupakan usia yang sangat menentukan dalam pembentukan karakter dan kepribadian seorang anak, usia itu sebagai usia penting bagi pengembangan intelegensi permanen dirinya, mereka juga mampu menyerap informasi yang sangat tinggi

Belajar pada anak usia dini dilakukan dengan interaksi anak dengan lingkungan belajarnya melalui pengalaman untuk mencapai tahap-tahap perkembangan. Perkembangan setiap anak tidaklah sama karena setiap individu memiliki perkembangan yang berbeda. Makanan yang bergizi dan seimbang serta stimulasi yang intensif sangat dibutuhkan untuk perkembangan dan pertumbuhan tersebut. Jika anak diberikan stimulus yang intensif, maka anak akan mampu menjalani tugas perkembangannya dengan baik.
Menurut Aisyah (2008) karakteristik anak usia dini antara lain: a) memiliki rasa ingin tahu yang besar, b) merupakan pribadi yang unik, c) suka berfantasi dan berimajinasi, d) masa paling potensial untuk belajar, e) menunjukkan sikap egosentris, f) memiliki rentang daya konsentrasi yang pendek, g) sebagai bagian dari makhluk sosial.

Melalui bermain ini anak dapat belajar bersosialisasi. Apabila anak belum dapat beradaptasi dengan teman lingkungnnya, maka anak-anak akan dijauhi oleh teman-temannya. Dengan begitu anak akan belajar menyesuaikan diri dan anak akan mengerti bahwa dia membutuhkan orang lain di sekitarnya.

\section{METODE}

Arikunto (2010) menyatakan penelitian tindakan kelas merupakan suatu pencermatan terhadap kegiatan yang sengaja dimunculkan, dan terjadi dalam sebuah kelas. Analisis data yang dilakukan adalah dengan cara membandingkan kondisi awal pra siklus kemudian dilanjutkan dengan siklus I dan siklus II untuk mengetahui tingkat perkembangan kecerdasan logika anak kelompok B melalui penerapan kegiatan bermain kolase angka berbasis potensi alam.

Penelitian Tindakan Kelas ini menggunakan dua siklus yang terdiri dari empat tahapan yaitu perencanaan (planning), tindakan (acting), pengamatan (observing), dan refleksi (reflecting). Setiap siklus juga terdiri dari dari dua pertemuan, dimana setiap pertemuan terdapat tiga kali penilaian 1). Mengenal bentuk media, 2). Mengenal konsep angka, dan 3). Menghitung jumlah bentuk benda. Kriteria dalam penilaian yaitu : BB (Belum Berkembang), MB (Mulai Berkembang), BSH (Berkembang Sesuai harapan), dan BSB (Berkembang Sangat Baik).

\section{HASIL DAN PEMBAHASAN}

Penelitian ini dilaksanakan di PAUD Mawar Al Barokah Kelurahan Padang Serai Kecamatan Kampung Melayu Kota Bengkulu dengan jumlah anak 25 orang yang terdiri dari 10 anak laki-laki dan 15 
orang anak perempuan. Adapun data hasil penelitian dapat diketahui sebagai berikut :

Tabel 1 Data Observasi Kecerdasan Logika Melalui Kegiatan Kolase Angka

Siklus 1 Pertemuan 1

\begin{tabular}{|c|c|c|c|c|c|c|}
\hline \multirow{2}{*}{$\begin{array}{c}\text { Kriteria } \\
\text { Penilaia } \\
\mathrm{n}\end{array}$} & \multicolumn{2}{|c|}{$\begin{array}{c}\text { Mengenal } \\
\text { bentuk } \\
\text { benda }\end{array}$} & \multicolumn{2}{|c|}{$\begin{array}{c}\text { Mengenal } \\
\text { konsep } \\
\text { angka }\end{array}$} & \multicolumn{2}{c|}{$\begin{array}{c}\text { Menghitun } \\
\text { g jumlah } \\
\text { bentuk } \\
\text { benda }\end{array}$} \\
\cline { 2 - 7 } & $\begin{array}{c}\text { Ana } \\
\mathrm{k}\end{array}$ & $\%$ & $\begin{array}{c}\text { Ana } \\
\mathrm{k}\end{array}$ & $\%$ & Anak & $\%$ \\
\hline $\mathrm{BB}$ & 2 & 8 & 2 & 8 & 2 & 8 \\
\hline $\mathrm{MB}$ & 7 & 28 & 9 & 3 & 8 & 3 \\
\hline $\mathrm{BSH}$ & 13 & 52 & 12 & 4 & 12 & 4 \\
& 3 & 12 & 2 & 8 & 3 & 1 \\
\hline BSB & 3 & & & & & 2 \\
\hline
\end{tabular}

Berdasarkan data hasil penelitian pada Tabel 1 dapat diketahui bahwa masih ada beberapa anak yang masuk dalam kategori Belum Berkembembang dan Mulai berkembang. Hal ini dikarenakan masih belum optimal dalam menyampaikan materi dan anak-anak masih belum fokus terhadap materi yang disampaikan. Oleh karena itu, perlu dilakukan perbaikan pembelajaran untuk pertemuan berikutnya.

Tabel 2 : Data Observasi

Kecerdasan Logika Melalui Kegiatan

Kolase Angka Siklus 1 Pertemuan 2

\begin{tabular}{|c|c|c|c|c|c|c|}
\hline \multirow{2}{*}{$\begin{array}{c}\text { Kriteria } \\
\text { Penilaian }\end{array}$} & \multicolumn{2}{|c|}{$\begin{array}{c}\text { Mengenal } \\
\text { bentuk } \\
\text { benda }\end{array}$} & \multicolumn{2}{|c|}{$\begin{array}{c}\text { Mengenal } \\
\text { konsep } \\
\text { angka }\end{array}$} & \multicolumn{2}{c|}{$\begin{array}{c}\text { Menghitung } \\
\text { jumlah } \\
\text { bentuk } \\
\text { benda }\end{array}$} \\
\cline { 2 - 8 } & Anak & $\%$ & Anak & $\%$ & Anak & $\%$ \\
\hline BB & 1 & 4 & 1 & 4 & 1 & 4 \\
\hline MB & 4 & 16 & 6 & 24 & 5 & 20 \\
\hline BSH & 12 & 48 & 11 & 44 & 10 & 40 \\
\hline BSB & 8 & 32 & 7 & 28 & 9 & 36 \\
\hline
\end{tabular}

Dari hasil penelitian pada Tabel 2 terlihat bahwa hasil yang diperoleh belum maksimal dan belum mencapai target yang diinginkan. Oleh karena itu, perlu dirancang kembali kegiatan pembelajaran pada Siklus 2.
Tabel 3 Data Observasi Kecerdasan Logika Melalui Kegiatan Kolase Angka

Siklus 2 Pertemuan 1

\begin{tabular}{|c|c|c|c|c|c|c|}
\hline \multirow{2}{*}{$\begin{array}{c}\text { Kriteria } \\
\text { Penilaia } \\
\text { n }\end{array}$} & \multicolumn{2}{|c|}{$\begin{array}{c}\text { Mengen } \\
\text { al } \\
\text { bentuk } \\
\text { benda } \\
\end{array}$} & \multicolumn{2}{|c|}{$\begin{array}{c}\text { Mengena } \\
1 \text { konsep } \\
\text { angka }\end{array}$} & \multicolumn{2}{|c|}{$\begin{array}{c}\text { Menghitun } \\
\text { g jumlah } \\
\text { bentuk } \\
\text { benda }\end{array}$} \\
\hline & $\begin{array}{c}\text { Ana } \\
k\end{array}$ & $\%$ & $\begin{array}{c}\text { Ana } \\
k\end{array}$ & $\%$ & $\begin{array}{c}\text { Ana } \\
\mathrm{k}\end{array}$ & $\%$ \\
\hline $\mathrm{BB}$ & 0 & 0 & 0 & 4 & 1 & 4 \\
\hline $\mathrm{MB}$ & 2 & 8 & 3 & 12 & 2 & 8 \\
\hline $\mathrm{BSH}$ & 13 & $\begin{array}{l}5 \\
2 \\
\end{array}$ & 12 & 48 & 11 & 44 \\
\hline $\mathrm{BSB}$ & 10 & $\begin{array}{l}4 \\
0\end{array}$ & 10 & 40 & 11 & 44 \\
\hline
\end{tabular}

Berdasarkan Tabel 3 kemampuan anak pada siklus 2 pertemuan ke 1 sudah mulai meningkat tetapi masih perlu melaksanakan kegiatan pembelajaran agar mencapai target yang diinginkan. Untuk itu perlu diadakan siklus 2 pertemuan 2 .

Tabel 4 Data Observasi Kecerdasan Logika Melalui Kegiatan Kolase Angka

Siklus 2 Pertemuan 2

\begin{tabular}{|c|c|c|c|c|c|c|}
\hline \multirow[t]{2}{*}{$\begin{array}{l}\text { Kriteria } \\
\text { Penilaian }\end{array}$} & \multicolumn{2}{|c|}{$\begin{array}{l}\text { Mengenal } \\
\text { bentuk } \\
\text { benda }\end{array}$} & \multicolumn{2}{|c|}{$\begin{array}{c}\text { Mengenal } \\
\text { konsep } \\
\text { angka }\end{array}$} & \multicolumn{2}{|c|}{$\begin{array}{l}\text { Menghitung } \\
\text { jumlah bentuk } \\
\text { benda }\end{array}$} \\
\hline & Anak & $\%$ & Anak & $\%$ & Anak & $\%$ \\
\hline BB & 0 & 0 & 0 & 0 & 0 & 0 \\
\hline MB & 0 & 0 & 0 & 0 & 0 & 0 \\
\hline $\mathrm{BSH}$ & 8 & 32 & 9 & 36 & 7 & 28 \\
\hline BSB & 17 & 84 & 16 & 64 & 18 & 72 \\
\hline
\end{tabular}

Kegiatan pembelajaran yang dilaksanakan pada siklus 2 pertemuan 2 mengalami peningkatan dan sesuai dengan target yang diinginkan. Pada pertemuan ini, anak sudah bisa mengenal bentukbentuk benda. Anak-anak sudah dapat menyebutkan nama benda yang akan dijadikan gambar kolase dan dapat menyebutkan ciri-ciri benda tersebut serta dapat menggunakan kearifan lokal yang sesuai kedalam media gambar kolase. Seperti pada gambar apel, anak-anak memilih kulit bawang merah dan daun jeruk sebagai bahan kolase. Pada tahap mengenal konsep angka dan menghitung jumlah bentuk benda, anak-anak dapat 
menyebutkan dan menuliskan angka yang sesuai dengan gambar kolase.

Peningkatan tersebut terjadi pada kategori anak Berkembang Sangat Baik (BSB) yakni pada tahapan mengenal bentuk benda sebesar $84 \%$, mengenal konsep angka sebesar $64 \%$, dan pada tahapan menghitung jumlah bentuk benda sebesar 72\%. Artinya kegiatan melalui media kolak (Kolase Angka) berbasis kearifan lokal mampu meningkatkan kecerdasan logika anak usia dini.

\section{PEMBAHASAN}

Penelitian ini difokuskan untuk mengetahui perkembangan kecerdasan logika matematika anak usia dini melalui kegiatan kolase dengan kriteria penilaian mengenal bentuk benda, mengenal konsep angka, dan menghitung jumlah bentuk benda.

Pada siklus pertama, banyak anakanak yang sudah dapat mengidentifikasi nama benda yang dimaksud, misalnya apel. Anak-anak sudah dapat menyebutkan warna buah dan warna daun apel. Namun, belum banyak anak mengetahui jumlah apel dan menuliskan angka yang sesuai pada gambar. Anak-anak juga masih fokus pada beberapa bahan alam saja. Sehingga ada beberapa gambar kolase anak yang belum menunjukkan konsep gambar dengan gambar yang sebenarnya. Kemampuan anak masih ada pada tahap Belum Berkembang dan Mulai Berkembang. Kemampuan anak pada siklus ini belum optimal, hal ini disebabkan beberapa anak yang belum fokus terhadap materi yang disampaikan.

Pada siklus kedua, kegiatan peembelajaran dilakukan dengan memperbaiki beberapa tahap yang menjadi kekurang pada siklus pertama. kegiatan awal pembelajaran dilakukan oleh guru dengan berbagi dan bertanya tentang kegiatan yang pernah dilakukan anak. Hal ini dimaksudkan agar anak menjadi tertarik dan mulai fokus terhadap kegiatan pembelajaran. Anak-anak kemudian diminta mengamati dan menjelaskan gambar sesuai dengan pengetahuan mereka. Dengan demikian, dapat diketahui pemahaman awal mereka tentang konsep mengenal bentuk benda dan mengenal konsep angka meningkat.

Peningkatan pada akhir siklus dua ini terjadi pada kategori anak Berkembang sangat Baik (BSB) yakni pada tahapan mengenal bentu benda sebesar $84 \%$, hal ini diketahui dari jumlah anak yang menggunakkan bahan alam yang sesuai dengan gambar yang seharusnya. Pada tahap mengenal konsep angka sebesar 64\%. Kemampuan anak pada tahap ini masih banyak yang berada tahap Berkembang Sesuai Harapan dan pada tahapan menghitung jumlah bentuk benda sebesar $72 \%$. Pada tahapan menghitung jumlah bentuk benda, tidak semua anak dapat langsung menjawab dengan benar. Masih ada beberapa anak yang terlihat masih berpikir terlebih dahulu sebelum menjawab. Namun secara keseluruhan, penelitian yang dilakukan dalam setiap pertemuan mengalami peningkatan.

\section{SIMPULAN}

Berdasarkan hasil penelitian yang telah dilakukan, dapat disimpulakn bahwa terjadi peningkatan kecerdasan logika melalui kegiatan kolak (kolase angka) berbasis potensi lokal pada anak usia dini. Hasil penelitian menunjukkan hasil siklus akhir kedua lebih tinggi daripada akhir siklus pertama. Di samping itu, dari proses pembelajaran tampak menyenangkan dengan menggunakan bahan alam yang mudah didapat, siswa menjadi lebih aktif, antusias, dan kreatif.

\section{UCAPAN TERIMA KASIH}

Peneliti menyampaikan Ucapan terima kasih kepada Kepala Sekolah, Guru dan siswa PAUD Mawar Al Barokah serta teman sejawat yang telah banyak membantu dan memperlancar penelitian ini.

\section{DAFTAR PUSTAKA}

Agustian, Ary Ginanjar. 2001. ESQ Berdasarkan 6 Rukun Iman dan 5 Rukun Islam;Rahasia sukses Membangun Kecerdasan Emosi dan Spiritual. Arga; Jakarta 
Aisyah, Siti. 2008. Perkembangan dan Konsep Dasar Pengembangan Anak Usia Dini. Universitas Terbuka: Jakarta

Arikunto, Suharsimi. 2008. Prosedur Penelitian Suatu Pendekatan Praktik. Jakarta: Rineka Cipta

Departemen Pendidikan Nasional, 2001. Pedoman Pembelajaran Bidang Pengembangan fisik di Taman Kanak-Kanak. Direktorat Jenderal Manajemen Pendidikan Dasar dan Menengah, Direktorat Pembinaan Taman Kanak-Kanak dan Sekolah Dasar: Jakarta

Fathani, Abdul Halim,Maskur Moch. 2009. Mathematical Intellegence. Ar-Ruzz Media: Jogjakarta

Hasiana, Isabella. dan Aniek Wirastania. 2017. Pengaruh Musik dalam Mengembangkan Kemampuan Mengenal Bilangan Siswa Kelompok A di Desa Lintang Surabaya. Jurnal Obsesi Vol 1 No 2: 2549-8959.

Makmun, Abin Syamsuddin. 2003. Psikologi Pendidikan. PT.Rosda Karya Remaja : Bandung

Mufarizuddin. 2017. Peningkatan Kecerdasan Logika Matematika Anak melalui Bermain Kartu Angka Kelompok B di TK Pembina Bangkinang Kota. Jurnal Obsesi Vol 1 No 1

Robert J Stanberg,dkk. 2008. Appiled Intelligance Kecerdasan Terapan. Pustaka Pelajar: Yogyakarta

Sujiono, Yuliani Nuraini. 2013. Konsep Dasar Pendidikan Anak Usia Dini. Universitas Negeri Jakarta:Jakarta

Sukmadinata, Nana Syaodih. 2005. Landasan Psikologi Proses Pendidikan. PT. Remaj: Bandung

Sulaiman,Umar. 2014. Mengidentifikasi Kecerdasan Anak. Jurnal AlRiwayah, Volume 7 Nomor 2, Agustus 2014 : 131-136.

Sumanto. 2005. Pengembangan Kreativitas Senirupa Anak TK. Departemen Pendidikan Nasional, Direktorat Jenderal Pendidikan Tinggi, Direktorat Pembinaan
Pendidikan Tenaga Kependidikan dan Ketenagaan Perguruan Tinggi: Jakarta

Trianto. 2008. Mendesain Penbelajaran Kontekstual di Kelas. Cerdas Pustaka Publisher : Jakartang 